\title{
ARASTIRMA RESEARCH
}

\section{Toplum Ruh Sağlığı Merkezine Kayıtlı Şizofreni Tanılı Hastalara Bakım Verenlerin Hastalığa Yönelik Iñançları ve Bakım Yükleri Schizophrenia-Related Beliefs and Care Burdens among Caregivers of Patients with Schizophrenia Registered at Community Mental Health Centers}

\author{
Çiğdem Bilgen 1D, Aysun Erdal ${ }^{2}$ iD, Naile Bilgili ${ }^{2}$ iD
}

\begin{abstract}
öz
Bu çalışmanın amacı Toplum ruh sağlğı merkezine kayıtlı olan şizofreni tanılı hastalara bakım verenlerin ruhsal hastalı̆a yönelik inançlarııın ve bakım yüklerinin belirlenmesidir. Araştırmanın örneklemini Keçören ve Etimesgut Toplum Ruh Sağlı̆ı Merkezleri'ne kayıtlı 218 şizofreni hastasının bakım verenleri oluşturmuştur. Veriler Nisan-Eylül 2018 tarihleri arasında sosyodemografik bilgi formu, Ruhsal Hastalı̆a Yönelik İnançlar Ölçeği ve Algılanan Aile Yükü Ölçeği kullanılarak toplanmıştır. Bakım verenlerin \%63.3'ü kadın, yaş ortalamaları $50.31 \pm 11.74^{\prime}$ tür. Ortalama $27.04 \pm 11.04$ yıldır bakım verdikleri şizofreni hastası ile birlikte yaşamaktadırlar. Ruhsal Hastalı̆a Yönelik İnançlar Ölçeği'nden alınan puan arttıkça Algılanan Aile Yükü Ölçeği'nden alınan puan da artmaktadır. Toplum ruh sağlığı merkezine düzenli olarak giden şizofreni hastasına bakım veren bireylerin, her iki ölçekten aldıkları puanlar gitmeyen hastalara bakım verenlere göre anlamlı düzeyde düşük bulunmuştur. Şizofreni hastalarının toplum ruh sağlığı merkezine gitme sıkıı̆ı arttıkça bakım verenlerin merkezin hizmetlerinden memnuniyet düzeyi artmaktadır. Sonuç olarak bakım verenin hastalığa yönelik inançları algıladığı bakım yükünü etkilemektedir. Toplum ruh sağlığı merkezlerinde verilen hizmete şizofreni hastalarının düzenli katılımı, bakım verenlerin hastalığa yönelik inançlarııın olumlu yönde değişimine ve algıladıkları bakım yükünün azalmasına katkı sağlamaktadır.
\end{abstract}

Anahtar sözcükler: Anne, çocuk-ebeveyn ilişkisi, içerik analizi, ebeveynlik, sharenting

\section{Abstract}

The aim of this study was to determine the beliefs and care burdens of mentally ill people who caregivers for schizophrenic patients registered in the community mental health center. The sample of the study consisted of caregivers of 218 schizophrenic patients registered in Keçioren and Etimesgut Community Mental Health Centers in Ankara. Data were collected with socio-demographic information form, Beliefs towards Mental IIIness Scale and Perceived Family Burden Scale at AprilSeptember 2018. 63.3\% of the caregivers are women, the mean age is $50.31 \pm 11.74$. As the score obtained from Beliefs Towards Mental IIIness Scale increases, the score derived from the Perceived Family Burden Scale also increases. Both scale scores of the caregivers for the schizophrenic patients who regularly visit to the center were found to be significantly lower than those who caregivers for patients who not visit. As the frequency of schizophrenia patients visit to the community mental health center increases, the satisfaction level of the caregivers increases with the services of the center. AS a conclusion, the care burden is affected by caregivers beliefs about the disease. Regular participation of schizophrenic patients to the service provided at community mental health centers contributes to the positive change of caregivers' beliefs about the disease and the reduction of the perceived care burden.

Keywords: Mother, child-parent relationship, content analysis, parenting, sharenting

${ }^{1}$ Gülhane Eğitim ve Araştırma Hastanesi, Ankara

${ }^{2}$ Gazi Üniversitesi, Ankara

Aysun Erdal, Gazi Üniversitesi Sağık Bilimleri Fakültesi Hemşirelik Bölümü, Ankara, Turkey

aysunmutlu92@hotmail.com

Geliş tarihi/Received: 08.06.2020 | Kabul tarihi/Accepted: 10.08.2020 | Çevrimiçi yayı//Published online: 25.12.2020 
GÜNÜMÜZ modern dünyasında ruh sağlığı sorunları hızla artı̧̧ göstermektedir (World Health Organization 2013, Vigo ve ark. 2016). En s1k görülen psikiyatrik hastaliklardan olan şizofreni düşünme, algılama, duygular, iletişim, benlik algisı ve davranıştaki bozulmalar ile karakterize, dünya çapında 20 milyon kişiyi etkileyen kronik ve şiddetli bir ruhsal bozukluktur (World Health Organization 2019). Dünya Sağlık Örgütü tarafindan küresel hastalık yüküne katkıda bulunan ilk 10 hastalık arasında gösterilen şizofreni bu nedenle önemli toplum sağllğı sorunlarından biridir (Fischer ve Buchana 2017). Günümüzde, şizofreni hastalığının tedavisinde, hastane temelli yaklaşımdan uzaklaşarak bireyin toplumda ve yaşamını sürdürdüğü ortam içinde tedavi edilmesi yaklaşımı benimsenmiştir. Bu sayede toplumsal ve mesleki beceriler geliştirerek bağımsız yaşayabilmeleri, hastalıkla başa çıkma becerilerinin artması ve uzun süreli hastaneye yatışların önlenmesi hedeflenmiştir (Chowdur ve ark. 2011). Türkiye'de toplum temelli ruh sağlığı anlayışının benimsenmesi ile Nisan 2009'dan bu yana Toplum Ruh Sağllğı Merkezleri (TRSM) hizmet vermeye başlamıştır (T.C. Sağlık Bakanlığı 2011). TRSM'ler kendisine bağı coğrafi bölgedeki ruhsal rahatsızlığı olan hastaları ve aileleri bilgilendirmekte, hastanın ayaktan tedavi ve takibini yapmaktadır. Ayrıca rehabilitasyon, psiko-eğitim, iş-uğraş terapisi, grup veya bireysel terapi gibi yöntemlerin kullanılarak hastanın toplum içinde yaşama becerilerinin artırılması da hedeflenmektedir (Sağlık Bakanlığı 2011, Çobadak 2015, Soygür 2016). TRSM'ler özellikle şizofreni spektrumu altındaki bozukluklar ve bipolar bozukluk tanısı almış ve kronik psikoz yaşayan birey ve ailelerine hizmet sunan önemli merkezler olup, hastalığın birey ve ailede ortaya çıkardığı değişim ve bu değiş̧imle baş etmesi için psikososyal uyumu sağlayabilecek kurumlar olarak hizmet vermesi planlanmıştır (T.C. Sağlık Bakanlığ 2011).

Ruhsal hastalıkların birey kadar aileyi de etkilediği bilinmektedir. Sağlık çalışanlarının, toplum temelli yaklaşımı benimsemesi ile hasta birey ile daha çok hastalığın akut döneminde birlikte iken, aile tüm günlerini hasta birey ile geçirmekte, hastanın bakım sorumluluğunu yürütmektedir (Köroğlu ve Hocaoğlu 2019). Bu durum bir dizi sorunu da beraberinde getirmektedir. Ailesiyle yaşayan hastaların çoğu tüm gününü evde geçirmekte, aileden en az bir kişi hasta bakımı nedeni ile sosyal yaşam ve üretim sürecinden uzak kalmakta, aileler fiziksel, ruhsal, sosyal ve ekonomik sorunlar yaşamaktadırlar. Hasta yakınları özellikle bakımdan sorumlu olan bireyler genellikle hasta ve hastalıkla ile ilgili yeteri kadar bilgiye sahip olamamakta veya ilgili kurumlardan yeterince destek alamamaktadırlar. Yaşanan tüm bu durumlar bakım yükü kavramının ruhsal hastalıklardaki boyutunu ön plana çıkarmaktadır (Yıldırım ve ark. 2017). Bakım yükü kavramı, 1950'lerde alan yazında yer almaya başlamış olup, hasta bir aile üyesine bakmak veya onunla birlikte yaşamaktan kaynaklanan günlük zorluklar, sorunlar ve olumsuz yaşam olaylarının tümünü ifade eden bir terimdir (Schene 1990). Bakım yükü kavramı nesnel ve öznel yük olmak üzere iki farklı fakat tamamlayıcı alt alandan oluşmaktadır. Nesnel yük; hastanın sosyal çevresi ile birlikte, davranışlarının ve hastalık semptomlarının sonuçları olarak kabul edilmektedir. Gelirin azalması, aile içi huzursuzluk, sosyal etkinliklere olan katılımın azalması gibi durumlar nesnel yükü ifade etmektedir. Öznel yük; hastanın rahatsızlık verici durum ve davranışlarının aile için oluşturduğu psikolojik sonuçları ve hissedilen kişisel sıkıntı düzeyini ifade etmektedir. Nesnel ve öznel yük birlikte toplam bakım yükünü ifade etmektedir (Ewigman 2011, Mantovani ve ark. 2016). Yapılan çalı̧̧malar hasta ve bakım verenin cinsiyetinin, hastalık şiddeti ve süresinin, ailenin başa çıkma biçimi, destek alıp almaması, şizofreninin nedenine ilişkin inançlarının ailenin yükünü etkilediğini ortaya koymuştur (Roick ve ark. 2007, Awad ve Voruganti 2008, 
Gülseren ve ark. 2010). Dünya Ruh Sağllğ̆ Federasyonu (World Federation of Mental Health) kronik hastalara bakım verenlerin yükünün küresel bir sorun olduğunu ve bu hastaların bakımının sürekli fiziksel, ruhsal ve ekonomik güç gerektirdiğini belirtmektedir. Dolayısıyla bakım verenler günlük yaşamlarında bir denge oluşturmaya gayret gösterirken ciddi stres ve bakım yükü ile karşı karşıya kalmaktadırlar (Chan 2011, Chaturverdi ve ark. 2014, Yazıc1 ve ark. 2016).

Şizofrenide bakım verenin yaşadığı bakım yükünün duygu dişavurum davranışlarının şiddetini etkilediği bilinmektedir (Akınc1 2019). Aile üyeleri genellikle üzüntü, öfke, suçluluk ve utanç gibi karmaşık duygular yaşamakta ve bu duyguların temelinde bilişsel süreçlerin yattığı ve hastalığa yönelik inanç ve tutumlarının etkili olduğu düşünülmektedir (Köroğlu ve Güleç 2007, Çam ve Bilge 2013). Yapılan çalışmalarda hastalığa yönelik olumsuz inanca sahip olan bakım verenin tedaviyi olumsuz etkilediği, tedaviye uyumu güçleştirip tıp dışında yardım arama davranışlarına yöneldiği ve toplum tarafından dışlanmaya maruz kaldığı tespit edilmiştir (Sağduyu ve ark. 2001, Çam ve Bilge 2013, Yalvaç ve ark. 2015, Sarıkoç ve ark. 2015, Bademli ve Lök 2017). Bu damgalanma sürecine sadece hastalar değil çoğu zaman aile üyeleri de maruz kalmaktadır. Toplum tarafından reddedilmek ailenin sosyal destek sistemlerinin kısıtlanmasına ve çaresizlik duygusunun artmasına neden olabilmektedir. Ayrıca oluşan olumsuz hastalık algısı, bakım verenlerin yüklerini ve sıkıntılarını artırabilecek etkisiz başa çıkma yöntemlerinin kullanımına neden olmaktadır (Maj ve Sartorius 2009, Sarıkoç ve ark. 2015). Hastalığın birey ve ailede ortaya çıkardığı değişim ve bu değişimle baş etmesi için psikososyal uyumu sağlayabilecek kurumlar olarak planlanan TRSM'lerde görev yapan hemşireler toplum ruh sağllğı hemşireliği kapsamında birey ve ailenin yaşam kalitesini artırmada, yaşadığı sorunlarla bas, etmede önemli role sahiptir. Kronik psikiyatrik hastalıkların yönetiminde multidisipliner bir ekip anlayışı benimsenmesi son derece önemli olup, ekibinin kilit üyesi hemşiredir. Hemşire hastanın olaylara karşı tepkilerini aktif olarak değerlendirebilmekte ve yönetebilmektedir (Bag 2012). Ayrıca, aileye yönelik müdahaleler geliştirerek, hastalığın tüm boyutlarıyla aile üyeleri tarafından öğrenilmesini, ailede yüksek duygu dişavurumun düzenlenmesini, bakım verenin hastalığa olan olumsuz inanç, tutum ve davranışlarının giderilmesini, tedavi sürecinden beklentilerinin gerçekçi olmasını, stresle baş etme ve sorun çözme becerilerini geliştirmesini sağlamaktadır (Falloon 2003).

Bu çalışmada, toplum ruh sağlı̆̆ merkezine kayıtlı olan şizofreni tanılı hastaların bakım verenlerinin; ruhsal hastalığa yönelik inançları ve bakım yüklerinin belirlenmesi amaçlanmaktadır. Araştırma, TRSM hizmetlerinin bakım vericiler üzerindeki etkisini değerlendirmesi ve sunulan bu hizmetlerin şizofreni hastalığının yönetimi konusunda önemli noktalar olan hastalığa yönelik inanç ve bakım yüküne etkisini incelemesi bakımından literatüre katkı sağlamaktadır. Araştırma, TRSM'lere kayıtlı şizofreni tanılı hastalara bakım verenlerin hastalığa yönelik inançları ile algıladıkları bakım yükü seviyesi nedir ve bakım verenlerin bakım yükü ve hastalığa yönelik inançları ilişkili midir sorularına cevap aramaktadır.

\section{Yöntem}

\section{Örneklem}

$\mathrm{Bu}$ araştırma; toplum ruh sağlığı merkezine kayıtlı şizofreni tanılı hastalara bakım verenlerin ruhsal hastalığa yönelik inançları ve bakım yüklerini belirlemek amacıyla planlanan tanımlayıcı bir çalışmadır. 
Araștırma, Ankara İli Büyükşehir Belediyesi sınırları içinde yer alan Devlet Hastaneleri ile Eğitim ve Araștırma Hastanelerine bagłı bes, TRSM' de gerçekleș,irilmek üzere planlanmıs,tır. Ruh sağlığı merkezlerine kayıtlı toplam 1000 şizofreni hastasının bakım verenleri araştırmanın evreni oluşturmaktadır. Araştırmamızın örneklem büyüklüğü, evreni bilinen örneklem formülü ile hesaplanarak, ulaşılması gereken en küçük örneklem sayısı hesaplamış ve 198 olarak bulunmuştur. Toplam 5 merkez arasından Keçiören ve Etimesgut Toplum Ruh Sağllğı Merkezleri kura yöntemi ile belirlenerek çalışma bölgesine karar verilmiştir. Araştırmamızın örneklemini Keçiören ve Etimesgut Toplum Ruh Sağlığı Merkezleri'ne kayıtlı 218 şizofreni tanılı hastaya bakım veren birey oluşturmuştur. Her aile için sadece bir bakım veren çalışmaya dahil edilmiştir.

Bakım verenlerin araştırmaya katılmaya gönüllü olması, anlama, algılama yeteneği ve sözel iletişim açısından sorunu olmaması, Türkçe konuşabilmesi ve anlayabilmesi, hastaya en az altı aydır bakım veriyor olması ve bakım verdikleri şizofreni tanılı hastanın TRSM'ye kayıtlı olması, araştırmaya dâhil edilme kriterleridir. Araştırmaya dahil edilme kriterlerden herhangi birine uymayan, psikiyatrik bozukluk öyküsü olan, bakım hizmetini ücret karşılığı yapan bakım verenler araştırmaya dahil edilmemiştir.

\section{Ölçekler}

\section{Sosyodemografik bilgi formu}

Araştırmacılar tarafından literatür incelenerek hazırlanmış bakım verenlerin ve şizofreni hastalarının sosyo-demografik özellikleri (yaş, cinsiyet, medeni durum, aile tipi, yakınlık derecesi, tanı süresi, bakım verme süresi), şizofreni hastasının TRSM'ye kayıt süresi, devam durumu, sıklığı gibi faktörler ile bakım verenlerin, TRSM'lerin şizofreni hastalarına sundukları hizmetten memnuniyet düzeyine ilişkin tanımlayıcı bilgileri içeren 16 soruluk anket formudur (Ensari ve ark. 2013, Gül ve ark. 2014, Hsiao ve Tsai 2015, Yu ve ark. 2017).

\section{Ruhsal Hastalığa Yönelik İnançlar Ölçeği (RHYİÖ)}

Ruhsal Hastalığa Yönelik İnançlar Ölçeği, Hirai ve Clum (2000) tarafindan ruhsal hastalığa yönelik farklı kültürel özelliklere sahip bireylerin olumlu ve olumsuz inançlarını belirlemek amacıyla oluşturulmuştur. Türkçe formunun geçerlilik güvenirliliği Bilge tarafından 2006 yılında yapılmıştır. Ölçek 6’lı likert tipte olup; tehlikelilik, çaresizlik ve kişiler arası beceri ve utanma alt ölçeği olmak üzere üç alt boyuttan oluşmaktadır. Ölçek ve alt boyutlarından alınan yüksek puan olumsuz inancı ifade etmektedir. Ölçeğin iç tutarlılık Cronbach alfa katsayısı 0.82 bulunmuştur. Alt ölçek Cronbach alfa değerleri 0.69- 0.80 arasında olup, ölçek ve alt ölçekler kabul edilebilir düzeyde iç tutarlılık göstermektedir. (Bilge 2006). Bu çalışmadan se ölçeğin Cronbach Alpha katsayısı 0.93 olarak bulunmuştur.

\section{Algılanan Aile Yükü Ölçeği (AAYÖ)}

Algılanan Aile Yükü Ölçeği, Levene ve arkadaşları (1996) tarafından geliştirilmiş, Türkçeye Arslantaş ve arkadaşları (2011) tarafindan uyarlanan ölçek dörtlü likert tipinde maddeden oluşmaktadır. Ölçeğin değerlendirilmesi iki basamakta gerçekleştirilmektedir: ilk aşama değerlendirmeleri toplam puanın nesnel bileşeni ( 0 ile 24 puan arasında); ikinci aşama değerlendirmeleri toplam puanın öznel bileşeni (0 ile 96 puan arasında), öznel ve nesnel puanların toplamı toplam yükü belirtmekte olup 0 ile 120 arasında puan alınmak- 
ta, puan arttıkça bakım verenin yük algısı artmaktadır. Ölçeğin Cronbach alfa iç tutarlılık katsayısı 0.916 olarak hesaplanmıştır (Arslantaş ve ark. 2011). Bu çalışmada ise ölçeğin Cronbach alfa katsayısı 0.85 olarak bulunmuştur.

Tablo 1. Katılımcıların demografik özellikleri ve TRSM hizmetlerinden yararlanma durumları

\begin{tabular}{|c|c|c|c|c|c|c|}
\hline Değişken & & $\mathbf{n}$ & $\%$ & ort \pm ss & $\min$ & $\max$ \\
\hline Bakım verenin yaş ortalaması & & 218 & 100 & $50.31 \pm 11.74$ & 17 & 80 \\
\hline Hastanın yaş ortalaması & & 218 & 100 & $42.12 \pm 14.02$ & 19 & 75 \\
\hline Ruhsal hastalık tanı süresi (yıl) & & 218 & 100 & $15.34 \pm 10.38$ & 1 & 44 \\
\hline Bakım verenin öğrenim durumu & Okuryazar değil & 5 & 2.3 & & & \\
\hline & Okuryazar & 15 & 6.9 & & & \\
\hline & illkokul & 72 & 33.0 & & & \\
\hline & Ortaokul & 23 & 10.6 & & & \\
\hline & Lise & 61 & 28.0 & & & \\
\hline & Üniversite & 42 & 19.3 & & & \\
\hline Bakım verenin medeni durumu & Evli & 167 & 76.6 & & & \\
\hline & Bekar & 51 & 23.4 & & & \\
\hline Aile tipi & Çekirdek aile & 144 & 66.1 & & & \\
\hline & Geniş aile & 65 & 29.8 & & & \\
\hline & Parçalanmış aile & 9 & 4.1 & & & \\
\hline Bakım verenin yakınlık derecesi & Annesi & 70 & 32.1 & & & \\
\hline & Babası & 33 & 15.1 & & & \\
\hline & Oğlu & 16 & 7.3 & & & \\
\hline & KIzI & 13 & 6.0 & & & \\
\hline & Kardeşi & 32 & 14.7 & & & \\
\hline & Eşi & 49 & 22.5 & & & \\
\hline & Diğer & 5 & 2.3 & & & \\
\hline Bakım verme süresi & 20 yıl altı & 59 & 27.1 & & & \\
\hline & $20-30 \mathrm{yll}$ & 75 & 34.4 & & & \\
\hline & 30 yıl üzeri & 84 & 38.5 & & & \\
\hline Hastanın cinsiyeti & Kadın & 92 & 42.2 & & & \\
\hline & Erkek & 126 & 57.8 & & & \\
\hline Hastanın öğrenim durumu & Okuryazar değil & 10 & 4.6 & & & \\
\hline & Okuryazar & 17 & 7.8 & & & \\
\hline & ìlkokul & 66 & 30.3 & & & \\
\hline & Ortaokul & 37 & 17.0 & & & \\
\hline & Lise & 73 & 33.5 & & & \\
\hline & Üniversite & 15 & 6.9 & & & \\
\hline TRSM'ye kayıtlı olduğu süre & 1 yıl ve daha az & 97 & 44.5 & & & \\
\hline & $2 \mathrm{yll}$ & 68 & 31.2 & & & \\
\hline & 3 yıl ve üzeri & 53 & 24.3 & & & \\
\hline TRSM'ye gitme sıklığı & Düzenli olarak gitmekte & 43 & 19.7 & & & \\
\hline & Haftada 1 ya da 2 kez & 31 & 14.2 & & & \\
\hline & Ayda 1 ya da 2 kez & 40 & 18.3 & & & \\
\hline & Ayda 1'den az & 104 & 47.7 & & & \\
\hline TRSM'ye düzenli gitme durumu & Evet & 71 & 32.6 & & & \\
\hline & Hayır & 147 & 67.4 & & & \\
\hline TRSM'ye düzenli gitmeme nedeni & Ulaşım problemi & 11 & 7.4 & & & \\
\hline & Hastanın istememesi & 90 & 60.8 & & & \\
\hline
\end{tabular}




\begin{tabular}{|c|c|c|c|}
\hline & $\begin{array}{l}\text { Hasta yakının isteme- } \\
\text { mesi }\end{array}$ & 11 & 7.4 \\
\hline & Diğer & 35 & 24.3 \\
\hline \multirow{4}{*}{$\begin{array}{l}\text { TRSM'ye kayıt sonrası hastaneye } \\
\text { yatış sayısı }\end{array}$} & Hiç & 147 & 67.4 \\
\hline & $1 \mathrm{kez}$ & 46 & 21.1 \\
\hline & $2 \mathrm{kez}$ & 21 & 9.6 \\
\hline & 3 kez ve üzeri & 4 & 1.9 \\
\hline \multirow{5}{*}{$\begin{array}{l}\text { TRSM hizmetine yönelik memnuni- } \\
\text { yet düzeyi }\end{array}$} & Çok iyi & 83 & 38.1 \\
\hline & İyi & 88 & 40.4 \\
\hline & Orta & 41 & 18.8 \\
\hline & Kötü & 4 & 1.8 \\
\hline & Çok kötü & 2 & 0.9 \\
\hline
\end{tabular}

TRSM: Toplum Ruh Sağlığı Merkezi

\section{Uygulama}

Araştırma için, Gazi Üniversitesi Etik Komisyonu'ndan etik izin (Tarih: 13/02/2018, Say1: 77082166-302.08.01-E.25910), Ankara Etimesgut Şehit Sait Ertürk Devlet Hastanesi ve Keçiören Eğitim ve Araştırma Hastanesi Başhekimliğinden yazılı olarak uygulama izinleri alınmıştır. Çalı̧̧maya katılacak bakım verenlerden yazılı bilgilendirilmiş gönüllü onam alınmıştır.

Araştırmada veriler, Sosyodemografik Bilgi Formu, RHYIÖ ve AAYÖ ile araştırmacılar tarafindan yüz yüze görüşme yolu ile bakım verenlerden elde edilmiştir. Nisan-Eylül 2018 tarihleri arasında aydınlatılmıs onamları alınarak veri toplama araçları TRSM' lerde toplam her bir bakım veren için 20 dakika sürede uygulanmıştır.

\section{İstatistiksel analiz}

Verilerin değerlendirilmesi ve analizi SPSS (Statistical Package for Social Sciences) 22 programı ile yapılmıştır. Tanımlayıcı istatistiklerin analizinde, sayı, yüzdeler, ortalama standart sapma kullanılmıştır. Nicel değişkenlerin istatistiksel değerlendirilmesinde ilk olarak Kolmogorov-Smirnov testi ile verilerin normal dağılıma uygunluğu incelenmiştir. İki bağımsız grubu karşılaştırmak için normal dağ 1 lım gösteren verilerde Student $\mathrm{t}$ testi, normal dağılım göstermeyen verilerde Mann-Whitney $U$ testi kullanılmış, ikiden fazla sayıda grubun karşılaştırılmasında ise normal dağılıma gösteren veriler için Tek Yönlü Varyans Analizi (One Way ANOVA), normal dağılıma uygunluk göstermeyen verilerin analizinde Kruskal Wallis testi kullanılmıştır. İkiden fazla grup bulunan analizlerde farkın hangi grup/gruplar arasında olduğunu tespit etmek için grupların varyansları homojen ise LSD, grupların varyansları heterojen ise Tamhane T2 çoklu karşılaştırma testleri kullanılmıştır. Normal dağılım göstermeyen değişkenler arasındaki ilişkileri incelemek için Spearman Korelasyon katsayısı kullanılmıştır. Yapılan istatistiksel analizler için anlamlılık düzeyi $\mathrm{p}<0.05$ olarak kabul edilmiştir.

\section{Bulgular}

Katılımcılar ve bakım verdikleri bireylerin demografik özellikleri ile TRSM hizmetlerinden yararlanma durumlarına ilişkin veriler Tablo 1'de sunulmuştur. Bakım verenlerin

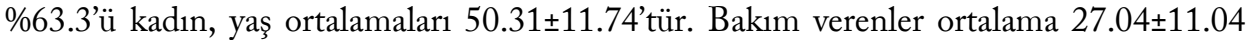
yıldır bakım verdikleri birey ile birlikte yaşamaktadırlar. Hastaların \%42.2'si kadın, yaş 
ortalamaları $42.12 \pm 14.02$ ' dir. Şizofreni hastalarının \%55.5’i bir yıldan daha uzun süredir TRSM'ye kayıtlı ve \%32.6'sı düzenli olarak TRSM'ye gittiğini ifade etmiştir. Düzenli gitmeme sebebi olarak \%60.8 ile hastanın istememesi ifade edilmiştir. Bakım verenlerin \%67.4'ü TRSM'ye kayıt sonrası hastalarının hastaneye hiç yatışlarının olmadığını ifade etmiştir. Bakım vericilerin \%70.5’i TRSM hizmetini çok iyi ve iyi olarak nitelendirmiştir.

Tablo 2. RHYiö ve AAYÖ ile alt boyutlarının puan ortalamaları $(n=218)$

\begin{tabular}{lccc}
\hline Ölçekler ve Alt Boyutları & ort $\pm \mathbf{s s}$ & min & max \\
\hline RHYiö Alt Boyutları & & & \\
\hline Tehlikelilik & $21.97 \pm 7.41$ & 7 & 40 \\
\hline Çaresizlik ve Kişilerarası Illişkilerde Bozulma & $30.92 \pm 11.36$ & 4 & 55 \\
\hline Utanma & $3.11 \pm 2.84$ & 0 & 10 \\
\hline RHYiö Ölçek Toplam Puanı & $56.01 \pm 19.87$ & 13 & 105 \\
\hline AAYÖ Alt Boyutları & & & \\
\hline Nesnel Puan & $7.51 \pm 6.51$ & 0 & 24 \\
\hline Öznel Puan & $20.74 \pm 15.57$ & 0 & 96 \\
\hline AAYÖ Toplam Puanı & $28.20 \pm 21.31$ & 0 & 120 \\
\hline
\end{tabular}

RHYiö: Ruhsal Hastalığa Yönelik Inançlar Ölçeği, AAYÖ: Algılanan Aile Yükü Ölçeği

Tablo 2'de bakım verenlerin RHYİÖ ve AAYÖ ile alt boyutlarından aldıkları puan ortalamaları gösterilmiştir. Buna göre, bakım verenlerin RHYİÖ toplam puan ortalaması

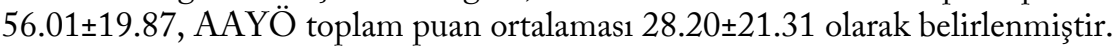

Tablo 3. Şizofreni hastalarına bakım verenlerin RHYiö ve AAYÖ ile alt boyut puanları arasındaki ilişki

\begin{tabular}{|c|c|c|c|c|}
\hline$(n=218)$ & Tehlikelilik & $\begin{array}{l}\text { Çaresizlik ve Kişilerarası } \\
\text { İlişkilerde Bozulma }\end{array}$ & Utanma & $\begin{array}{c}\text { RHYiÖ Toplam } \\
\text { Puan }\end{array}$ \\
\hline \multirow[t]{2}{*}{ Öznel Puan } & ${ }^{*} r=0.455$ & ${ }^{*} r=0.557$ & ${ }^{*} r=0.334$ & ${ }^{*} \mathrm{r}=0.559$ \\
\hline & $p=0.000$ & $p=0.000$ & $p=0.000$ & $p=0.000$ \\
\hline \multirow[t]{2}{*}{ Nesnel Puan } & ${ }^{*} \mathrm{r}=0.475$ & ${ }^{*} \mathrm{r}=0.575$ & ${ }^{*} \mathrm{r}=0.340$ & ${ }^{*} \mathrm{r}=0.558$ \\
\hline & $p=0.000$ & $p=0.000$ & $p=0.000$ & $p=0.000$ \\
\hline \multirow[t]{2}{*}{ AAYÖ Toplam Puan } & ${ }^{*} r=0.466$ & ${ }^{*} \mathrm{r}=0.567$ & ${ }^{*} \mathrm{r}=0.330$ & ${ }^{*} \mathrm{r}=0.549$ \\
\hline & $p=0.000$ & $p=0.000$ & $p=0.000$ & $p=0.000$ \\
\hline
\end{tabular}

*Spearman Korelasyon Analizi, p<0.05, RHYiÖ: Ruhsal Hastalığa Yönelik Inançlar Ölçeği, AAYÖ: Algılanan Aile Yükü Ölçeği

Tablo 3'te şizofreni hastalarına bakım verenlerin RHYIOÖ ve AAYÖ toplam puanları ile alt boyut puanları arasındaki ilişki gösterilmektedir. Bakım verenlerin AAYÖ toplam puanı ve alt boyut puanları ile RHYIÖ toplam puanı ve alt boyut puanları arasında pozitif yönde orta düzeyde ilişki saptanmıştır $(\mathrm{p}<0.05)$.

Tablo 4'te TRSM'ye kayıt süresi ve düzenli gitme durumu ile şizofreni hastalarına bakım verenlerin RHYİÖ ve AAYÖ alt boyutlarının ortalamaları karşılaştırılmıştır. TRSM'ye kayıt süresinin RHYIÖ'nün toplam puanı ve tehlikelilik, çaresizlik ve kişilerarası ilişkilerde bozulma alt boyut puanları ile AAYÖ'nün toplam puanı ve alt boyutları arasında anlamlı farklılık tespit edilmiştir. ( $p<0.05)$. TRSM'ye kayıt süresi ile RHYIOÖnün utanma alt boyutu arasında anlamlı farklılık tespit edilememiştir ( $p>0.05)$. Gruplar arası karşılaştırmada LSD, ve Tamhane T2 çoklu karş1laştırma testleri kullanılmış ve TRSM'ye üç yıl ve üzeri kayıtlı şizofreni hastasına bakım veren bireylerin, 1 yıl ve daha az süredir kayıtlı olan şizofreni hastasına bakım verenlere göre ölçekler ve alt boyutlarından aldıkları puanları, anlamlı olarak düşük saptanmıştır ( $\mathrm{p}<0.05)$. TRSM'ye düzenli olarak giden şizofreni hastalarına bakım verenlerin RHYIÖ, AAYÖ ve alt boyut puanları düzenli gitmeyen şizofreni hastalarının bakım verenlerine göre anlamlı olarak düşük 
tespit edilmiştir $(\mathrm{p}<0.05)$. Ayrıca araştırmada, şizofreni hastalarının TRSM'ye gitme sıklığ1 ile bakım vericilerin TRSM hizmetinden memnuniyet düzeyi arasından pozitif yönlü orta dereceli anlamlı bir ilişki saptanmıştır ( $r=0.461, \mathrm{p}=0.000)$.

Tablo 4. TRSM'ye kayıt süresi ve düzenli gitme durumu ile şizofreni hastalarına bakım verenlerin RHYiö ve AAYÖ alt boyutlarının puan ortalamalarının karşılaştırılması $(\mathbf{n}=\mathbf{2 1 8})$

\begin{tabular}{|c|c|c|c|c|c|c|c|}
\hline & Tehlikelilik & $\begin{array}{c}\text { Çaresizlik ve } \\
\text { Kişilerarası } \\
\text { İlişkilerde } \\
\text { Bozulma }\end{array}$ & Utanma & $\begin{array}{l}\text { RHYiö } \\
\text { Toplam } \\
\text { Puan }\end{array}$ & $\begin{array}{l}\text { Öznel } \\
\text { Puan }\end{array}$ & $\begin{array}{l}\text { Nesnel } \\
\text { Puan }\end{array}$ & $\begin{array}{c}\text { AAYö } \\
\text { Toplam } \\
\text { Puan }\end{array}$ \\
\hline \multicolumn{8}{|c|}{ TRSM'ye Düzenli Gitme Durumu } \\
\hline Evet & 88.15 & $\begin{array}{c}26.83 \\
\pm 12.47\end{array}$ & 73.29 & $\begin{array}{c}48.19 \pm 21 . \\
59\end{array}$ & 89.88 & 96.28 & 92.42 \\
\hline Hayır & 119.81 & $\begin{array}{c}32.90 \\
\pm 10.26\end{array}$ & 126.99 & $\begin{array}{c}59.78 \pm 17 \\
87\end{array}$ & 118.30 & 115.88 & 117.06 \\
\hline p & $\begin{array}{l}{ }^{*} U=3702 \\
p=0.001\end{array}$ & $\begin{array}{c}* * t=-3,810 \\
p=0.000\end{array}$ & $\begin{array}{c}* U= \\
2647 \\
p=0.000\end{array}$ & $\begin{array}{c}* * t=- \\
3,921 \\
p=0.000\end{array}$ & $\begin{array}{l}{ }^{*} U=3825 \\
p=0.002\end{array}$ & $\begin{array}{l}{ }^{*} U=4280 \\
p=0.031\end{array}$ & $\begin{array}{l}{ }^{*} U=4006 \\
p=0.007\end{array}$ \\
\hline \multicolumn{8}{|c|}{ TRSM'ye kayıt süresi } \\
\hline $\begin{array}{l}1 \text { yıl ve daha } \\
\text { az }\end{array}$ & 110,62 & $\begin{array}{c}32,81 \pm 12,0 \\
2\end{array}$ & 106,75 & $\begin{array}{c}59,40 \pm 21 \\
57\end{array}$ & 117,40 & 115,21 & 116,47 \\
\hline $2 \mathrm{yll}$ & 106,73 & $\begin{array}{c}30,88 \pm 10,6 \\
4\end{array}$ & 104,04 & $\begin{array}{c}56,27 \pm 17 \\
81\end{array}$ & 93,16 & 97,82 & 93,95 \\
\hline 3 yıl ve üzeri & 84,67 & $\begin{array}{c}27,86 \pm 10,3 \\
7\end{array}$ & 95,06 & $\begin{array}{c}49,98 \pm 17 \\
72\end{array}$ & 89,09 & 88,81 & 89,66 \\
\hline $\mathbf{p}$ & $\begin{array}{c}* * * K=6.492 \\
p=0.039\end{array}$ & $\begin{array}{c}* * * F= \\
3.117 \\
p=0.046\end{array}$ & $\begin{array}{c}* * * K W= \\
1.303 \\
p=0.521\end{array}$ & $\begin{array}{c}* * * * \mathrm{~F}=3.7 \\
18 \\
\mathrm{p}=0.026\end{array}$ & $\begin{array}{c}* * * K W=9 . \\
807 \\
p=0.007\end{array}$ & $\begin{array}{c}* * * K W=7 . \\
116 \\
p=0.028\end{array}$ & $\begin{array}{c}* * * K W=8 \\
646 \\
p=0.013\end{array}$ \\
\hline
\end{tabular}

* Mann-Whitney U testi kullanıımışıı, ${ }^{* * B a g ̆ ı m s ı z ~ g r u p l a r d a ~ t ~ t e s t i, ~}{ }^{* * *}$ Kruskall walls testi, ${ }^{* * * *}$ Tek Yönlü Varyans Analizi (One Way ANOVA) kullanılmıştır, p<0.05; RHYï̈: Ruhsal Hastalı̆a Yönelik İnançlar Ölçeği, AAYÖ: Algılanan Aile Yükü Ölçeği, TRSM: Toplum Ruh Sağlığı Merkezi

Bu bulgulara ek olarak çalışmaya katılan bakım verenlerin, bakım verdikleri süre ile AAYÖ ve öznel alt boyutundan alınan puan arasında anlamlı fark tespit edilmiştir (KW=7.015, p=0.030; KW=8.247, p=0.016). Gruplar arası karş1laştırmada Tamhane T2 çoklu karşılaştırma testi kullanılmı̧ ve 30 yıl ve üzeri bakım veren bireylerin 20 yıl altı ve 20-30 yıldır bakım verenlere göre ölçek puanı anlamlı derecede yüksek saptanmıştır $(\mathrm{p}<0.05)$. Ayrıca erkek cinsiyette hastaya bakım verenlerin $(\mathrm{U}=4826, \mathrm{p}=0.034)$ ve parçalanmış aile tipine sahip hastanın bakım verenlerinin nesnel aile yükü puanı anlamlı olarak yüksek bulunmuştur (KW=6.673, p=0.036). Bakım verenin cinsiyeti, eğitim seviyesi ve yakınlık derecesi ile AAYÖ ölçeği ve alt boyut puanları arasında anlamlı bir fark tespit edilememiştir $(\mathrm{p}>0.05)$.

\section{Tartışma}

TRSM'ye kayıtlı olan şizofreni tanılı hastaların bakım verenlerinin; ruhsal hastalığa yönelik inançları ve bakım yüklerinin belirlenmesini amaçlayan bu çalışmada AAYÖ toplam puan ortalaması $28.20 \pm 21.31$ bulunmuştur. Literatürde benzer çalışmaların sonuçları ile bu çalışmadan elde edilen puan ortalamaları karşılaştırıldığında bu çalışmadan elde edilen bakım yükü puanının düşük olduğu tespit edilmiştir (Arslantaş ve ark. 2012, Bayrak 2013, Yıldırım ve ark. 2014). Bu çalışmada bakım yükünün düşük olması örneklem grubunun TRSM hizmetlerinden yaralanmasının olumlu etkileri olarak değerlendirilebi- 
lir. Benzer şekilde Ayhan'ın (2019) yapmış olduğu çalışmada da TRSM hizmetlerinden düzenli olarak faydalanan şizofreni hastalarının yakınlarının bakım yükü bu hizmetten yararlanmayanların bakım yükü puanlarından anlamlı olarak düşük olduğu saptanmıştır. TRSM'ler tarafından izlenen şizofreni hastalarına verilen hizmetlerin yaşam kalitesini, sosyal uyumu artırdığı, hastalık ataklarını ve yeti yitimini azalttığı belirtilmektedir (Ensari ve ark. 2013, Gül ve ark. 2014). Dolayısı ile hastalardaki bu tür gelişmeler bakım verenlerin yükünü önemli derecede azaltacağı gibi bakım verenlere yönelik hizmetler de bakım verenlerin durumunu olumlu yönde etkilemekte ve bakım yükünü azaltmaktadır (Pazvantoğlu ve ark. 2014). Bulut ve ark. (2016) tarafindan yapılan randomize olmayan müdahale çalışmasında bakım verici bireylere psikoeğitim düzenlenmiş ve eğitim sonunda bakım yükü algısında eğitim verilmeyen bakım vericilere göre anlamlı düşüş saptanmiştır.

Araştırmada RHYIOÖnün alt boyutları ve toplam ölçek puan ortalaması değerlendirildiğinde bakım verenlerin hastalığa yönelik orta düzeyde olumlu inanca sahip olduğu belirlenmiştir. Sağlık profesyonelleri ve formal bakım vericiler ile aynı ölçüm aracı kullanılarak yapılan çalışmalarda da elde edilen sonuçlar bu çalışmanın sonuçları ile benzerlik göstermektedir (Y1ldırım ve ark. 2018, Duman ve ark. 2019, Gökmen ve ark. 2019). Yapılan çalışmalar bakım verenlerin ve genel toplumun hastalığa yönelik inançlarının yaş, cinsiyet, kişilik yapısı ve eğitim düzeyi gibi demografik değişkenler ve kültürden etkilendiğini göstermektedir (Caqueo-Urízar ve ark. 2016, Patikula 2017). Bakım verenlerin hastalığa yönelik inançlarının olumlu olarak değişimi noktasında TRSM'lerde bakım veren aile üyeleri için düzenlenen psikoeğitimler çok büyük öneme sahiptir. Bakım verenlerin eğitim programlarına katılmaları; hasta yakınlarının karşılaştığı bakım güçlüklerinin azalmasını, hastalık hakkında olan bilgilerinin artmasını ve hastalık ve yaşanan sıkıntılar karşısında daha etkili baş etme yöntemleri geliştirmelerini sağlamaktadır (Ensari ve ark. 2013). Mehrotra ve ark. (2018) tarafından yapılan çalışma şizofreniye yönelik inançların olumlu yönde değişimi için eğitim müdahalelerinin etkili olabileceğini düşündürmektedir. Çalışma ailede bakım veren bireylerin 1993-2016 yılları arasındaki 23 yıllık bir dönemdeki değiş̧iklikleri incelenmiş ve 80 bakım verende, 23 yıl içerisinde hastalı̆̆a yönelik pozitif algının oluştuğu saptanmıştır. Çalışma, zaman içerisinde hastalığa yönelik sağlık okuryazarlığının artmasının bu sonucu doğurduğunu vurgulamaktadır (Mehrotra ve ark. 2018).

Araştırmada AAYÖ toplam puanı ve alt boyut puanları ile RHYIÖ toplam puanı ve alt boyut puanlarının tümü arasında pozitif yönde orta düzeyde ilişki saptanmıştır. Çalı̧̧madaki bu sonuçlar dikkate alındığında; ruhsal hastalığa yönelik olumsuz inançların, algılanan bakım yükünü artırdığı söylenebilir. Çalışmanın bulgularına benzer şekilde Akıncı (2019) tarafından yapılan çalışmada da şizofreni hastalarına bakım verenlerin algılanan aile yükü ölçek puanı ile ruhsal hastalığa yönelik inançlar ölçeği toplam puanı ve bu değişkenin iki alt boyutu olan tehlikelilik ve çaresizlik ve kişilerarası ilişkilerde bozulma puanları arasında pozitif yönde ve anlamlı bir ilişki görülmüştür. Olumsuz hastalık algısının, bakım verenlerin yüklerini ve sıkıntılarını artırabilecek etkisiz başa çıkma stratejileri kullanımını artırdığını destekleyen çalı̧̧malar da bulunmaktadır (Segal ve ark. 2005, Rexhaj ve ark. 2016). Ruhsal hastalığa yönelik inançlar bireylerin bu hastalığa ve bu hastalığa sahip bireye karşı olan olumlu veya olumsuz algılarının düzeyini yansıtmaktadır. Bakım veren hastalığın doğası gereği meydana gelen negatif veya pozitif belirtileri hastalığa yönelik olumsuz inançları ile bağdaştırabilmekte, bu durum şizofreni hastası bireyin olumsuz değerlendirilmesi ve damgalanmasına neden olmaktadır. Bu nedenle 
olumsuz inançların algılanan yük ile ilişkili olduğu ve bakım yükünü arttırdığı belirtilmektedir (Hirai ve Clum 2000, Bilge 2006, Akınc1, 2019).

Araştırmada TRSM' ye kayıt süresi ve düzenli katılımın, hastanın hastaneye yatış sayısının azalmasında, inançların olumlu yönde değişiminde ve algılanan aile yükünün azalmasında etkili faktörler olarak tespit edilmiştir. Ayrıca hastanın TRSM'ye gitme sıklığ 1 arttıkça bakım vericinin hizmetten memnuniyet düzeyinin arttığı saptanmıştır. Erşan (2019) tarafından yapılan çalışmada en az 1 yıllık TRSM'ye kayıt süresine sahip 400 şizofreni hastasının kayıt öncesi ve sonrasındaki hastaneye yatış oranları değerlendirilmiş, kayıt öncesi ve sonrası yıllık yatış oranları istatistiksel olarak anlamlı değişim göstermiş, TRSM'ye kayıt sonrası yıllık yatı̧̧ oranlarının \%54.58 azaldığı tespit edilmiştir. Özdemir ve ark. (2017) yapmış olduğu çalışmada TRSM'de ve poliklinikte şizofreni tanısı ile en az bir yıldır düzenli olarak izlenen hastalar ve bakım verenleri ile yürütülen çalışmada poliklinikte takipli hastaların bakım verenlerinin bakım veren yükü daha yüksek tespit edilmiştir. Klinik değerlendirmede pozitif ve negatif belirtiler TRSM'nin takip ettiği şizofreni hastalarında anlamlı olarak düşük puan, iç görü ve tedavi uyumunda olumlu yönde anlamlı farklılık saptanmıştır. İşlevsellik alanlarında TRSM takipli şizofreni hastalarında 'özerklik', 'bilişsel işlevsellik', 'boş zaman etkinlikleri' alanlarında poliklinik grubuna göre daha olumlu davranış gösterdikleri belirlenmiştir (Özdemir ve ark 2017).

Çalışmada bakım verilen süre, bakım verenlerin yükünü etkileyen faktörlerden biri olarak tespit edilmiştir. Bakım verenin cinsiyeti, eğitim seviyesi ve yakınlık derecesinin bakım yükünü etkilemediği saptanmıştır. Çalışmada bakım verici cinsiyeti ve yakınlık derecesi bakımından homojen bir dağılımın olmasının bu sonucu doğurduğu düşünülmektedir. Benzer şekilde ülkemizde yapılan bir çalışmada bakıcının cinsiyeti ile yük arasında bir ilişki saptanmamıştır (Aydın ve ark. 2009). Literatür incelendiğinde kadın cinsiyet, düşük eğitim seviyesi, düşük aile gelir düzeyi, semptomların şiddeti, yetersiz sosyal destek, uygunsuz baş etme stratejileri, bakım verenin ebeveyn olması, bakım verende kronik hastalık varlığı, hastanın cinsiyeti (erkek cinsiyet) ve uzun hastalık tanı süresinin yüksek aile yükü ile ilişkili olduğu bulunmuştur (Gülseren ve ark. 2010, Çabuk 2014, Hsiao ve Tsai 2015, Mantovani ve ark. 2016, Caqueo-Urízar ve ark. 2016, Yu ve ark. 2017, Hajebi ve ark. 2019, Rahmani ve ark. 2019, Siddiqui ve Khalid 2019, Rhee ve Rosenheck 2019, Yu ve ark. 2019). Bu sonuçlara benzer şekilde bu çalışmada da erkek cinsiyette hastaya bakım verenlerin ve parçalanmıs aile tipine sahip hastanın bakım verenlerinin nesnel aile yükü puanı anlamlı olarak yüksek bulunmuştur.

\section{Sonuç}

Çalışmada, TRSM'lere kayıtlı şizofreni hastalarına bakım verenlerin algıladığı bakım yükü nispeten düşük, hastalığa yönelik olumsuz inançları orta düzeyde bulunmuştur. Bakım verenlerin algıladığı yük ile hastalığa yönelik inançlarının pozitif ilişkili olduğu saptanmıştır. TRSM' ye kayıt süresi ve düzenli katılım, hastanın hastaneye yatış sayısının azalmasında, olumsuz inançların olumlu yönde değişiminde ve algılanan aile yükünün hafiflemesinde etkili faktörler olarak değerlendirilmiştir. TRSM'nin şizofreni hastası bireyin yaşamındaki olumlu etkileri bakım verenin memnuniyet düzeyini arttırmaktadır. $\mathrm{Bu}$ nedenle bakım veren bireylerin algıladıkların yükün azaltılması için TRSM'den hizmet almayan şizofreni hastaların belirlenmesi, bu kurumların halka tanıtılması ve kurumun sağladığı hizmetlerden yararlanma oranının artırılması için uygun planlamaların 
yapılması önerilmektedir. Ayrıca TRSM'lerin ailelere psikoeğitim vererek hastalığa yönelik inançların olumlu yönde değiştirilmesinde etkin rol alması önerilmektedir.

Çalışmadan elde edilen bazı veriler bakım verenlerin ifadelerine dayalı olduğu için hatırlama ve yanıltıcı cevaplar verilmesi gibi durumlar araştırmanın sınırlılığını oluşturmaktadır. Çalışmanın bakım veren bireyler üzerine odaklanması ve örneklem sayısının istatiksel olarak hedeflenin üzerinde olması çalışmaya güç katmıştır. Ayrıca TRSM hizmetlerinin bakım verenler üzerindeki etkisini değerlendirmesi ve sunulan hizmetlerin etkisinin görünür hale getirmesi bakımından literatüre önemli katkı sağlamaktadır. Bakım verenlerin TRSM'lerin hangi hizmetlerinden yararlandıkları ve bu hizmetlerin etkileri konusunda daha detaylı çalışmaların yapılması ve çalı̧̧ma verilerine TRSM çalışanlarının şizofreni hastası ve bakım veren ilgili değerlendirmelerinin de eklenmesi önerilmektedir.

\section{Kaynaklar}

Akıncı ÜE (2019) Şizofreni hastalarının yaşam nitelikleri, hasta yakınlarının psikopatolojiye yönelik inançları, stresle başa çıkma tarzları, algılanan aile yükleri ve duygu dışavurumları arasındaki ilişkilerin incelenmesi (Yüksek lisans tezi). Ankara, Başkent Üniversitesi.

Arslantaş H, Adana F (2012) Factors affecting caregivers' burden and emotional expression of patients with schizophrenia. Anadolu Psikiyatri Derg, 13:8-15.

Aydın A, Eker SS, Cangür Ş, Sarandöl Ş, Kırlı A (2009) Şizofreni hastalarında bakım veren külfet düzeyinin sosyodemografik değişkenler ve hastalı̆ı̆n özellikleri ile ilişkisi. Noro Psikiyatri Ars, 46(Özel Sayı):10-14.

Ayhan Gıynaş M (2019) Toplum ruh sağlı̆ı merkezi hizmetlerinden yararlanan şizofreni tanılı hastaların yakınlarındaki bakım yükü: karşıllaştırmalı bir çalışma. Cukurova Medical Journal, 44:92-99.

Awad GA, Voruganti LNP (2008) The burden of schizophrenia on caregivers. Pharmacoeconomics, 26:149-162.

Bademli K, Lök N (2017) Kronik ruhsal hastalıılarda yardım arama davranışları. Psikiyatride Güncel Yaklaşımlar, 9:136-146.

Bag B (2012) Toplum ruh sağlığı merkezlerinde hemşirenin rolü: İngiltere örneği. Psikiyatride Güncel Yaklaşımlar, 4:465-485.

Bayrak YB (2013) Şizofren hastaların aile üyelerinin algılanan aile yükünün ve yaşam kalitesinin belirlenmesi (Yüksek lisans tezi). Sivas, Cumhuriyet Üniversitesi.

Bilge A (2006) Ruhsal hastalı̆ga yönelik inançlar ölçeği geçerlilik ve güvenirlik çalışması (Doktora tezi). İzmir, Ege Üniversitesi.

Bulut $\mathrm{M}$, Arslantaş H, Ferhan Di (2016) Effects of psychoeducation given to caregivers of people with a diagnosis of schizophrenia. Issues Ment Health Nurs, 37:800-810.

Çabuk M (2014) Psikoeğitimin şizofreni ailelerinin yük algılarına olan etkisi (Yüksek lisans tezi). Aydın, Adnan Menderes Üniversitesi.

Çam 0, Bilge A (2013) Türkiye'de ruhsal hastalığa/hastaya yönelik inanç, tutum ve damgalama süreci: Sistematik derleme. Psikiyatri Hemşireliği Dergisi, 4:91-101.

Caqueo-Urizar A, Urzúa A, Jamett PR, Irarrazaval M (2016) Objective and subjective burden in relatives of patients with schizophrenia and its influence on care relationships in Chile. Psychiatry Res, 237:361-365.

Chan SW (2011) Global perspective of burden of family caregivers for persons with schizophrenia. Arch Psychiatr Nurs, 25:339349 .

Chaturverdi S, Hamza A, Sharma M (2014) Changes in distressing behavior perceived by family of persons with schizophrenia at home - 25 years later. Indian J Psychol Med, 36:282-287.

Chowdur R, Dharitri R, Kalyanasundaram S, Suryanarayana RN (2011) Efficacy of psychosocial rehabilitation program: The RFS experience. Indian J Psychiatry, 53:45-48.

Çobadak A (2015) Toplum ruh sağlı̆ı merkezlerinde çalışan personelin, empatik eğilim, psikolojik dayanıkllık, öz yeterlilik ve problem çözme becerisi düzeylerinin değerlendirilmesi (Yüksek lisans tezi). Ankara, Gazi Üniversitesi.

Demir Gökmen B, Okanlı A (2019) Özel bakım merkezlerinde çalışan bakım elemanlarına verilen psikoeğitimin şizofreniye yönelik inançlara etkisi. Psikiyatri Hemşireliği Dergisi, 10:20-27. 
Duman B, Çolak B, Ünalp C, Taşçı D, Kumbasar H, Kar İ et al. (2019) Tıp eğitiminin ruhsal hastalıklara yönelik tutumlara etkisi. Türkiye Aile Hekimliği Dergisi, 23:141-149.

Ensari H, Gültekin BK, Karaman D, Koç A, Beşkardeş AF (2013) Bolu Toplum Ruh Sağlığı Merkezi hizmetlerinin şizofreni hastalarındaki yaşam kalitesi, yeti yitimi, genel ve sosyal işlevsellik üzerine etkisi: Bir yıllık izleme sonuçları. Anadolu Psikiyatri Derg, 14:108-114.

Erşan EE (2019) Hospitalization and some sociodemographic characteristics of patients registered with a community mental health center. Community Ment Health J, 56:498-505.

Ertekin Pinar S, Sabanciogullari S (2019). The relationship between functional recovery and quality of life in patients affected by schizophrenia and treated at a community mental health center in Turkey. Perspect Psychiatr Care, 56:448-454.

Ewigman N (2011) Encyclopedia of Clinical Neuropsychology, 3nd ed. (Eds Kreutzer JS, DeLuca J, Caplan B): 1018-1031. New York, NY, Springer.

Falloon IRH (2003) Family interventions for mental disorders: efficacy and effectiveness. World Psychiatry. 2:20-28.

Fischer BA, Buchanan RW (2017) Schizophrenia in adults: Epidemiology and pathogenesis. https://www.uptodate.com/contents/schizophrenia-in-adults-epidemiology-and-pathogenesis. (3 0cak 2020'de ulaşıldı).

Gibbons JS, Horn SH, Powell JM (1984) Schizophrenic patients and their families: a survey in a psychiatric service based on a DGH unit. Br J Psychiatry, 144:70-77.

Gül E, Can DÖ, Şahin EH, Şahin Ş, Şimşek E (2014) Kırıkkale toplum ruh sağlığı merkezi'nde takip edilen şizofreni hastalarının değerlendirilmesi. Kırıkkale Üniversitesi Tıp Fakültesi Dergisi.16(2):15-19.

Gülseren L, Cam B, Karakoç B, Yiğit T, Danacı AE, Çubukçuoğlu Z et al. (2010) The perceived burden of care and its correlates in schizophrenia. Turk Psikiyatri Derg, 21:203-212.

Hajebi A, Naserbakht M, Minoletti A (2019) Burden experienced by caregivers of schizophrenia patients and its related factors. Medical Journal of the Islamic Republic of Iran, 33:54-60.

Hirai M, Clum GA (2000) Development, reliability, and validity of the beliefs toward mental illness scale. J Psychopathol Behav Assess, 22:221-236.

Hsiao CY, Tsai YF (2015) Factors of caregiver burden and family functioning among Taiwanese family caregivers living with schizophrenia. J Clin Nurs, 24:1546-1556.

Köroğlu A, Hocaoğlu Ç (2019) Şizofrenide aile yükü, aile işlevleri ve başa çıkma tutumları arasındaki ilişkinin incelenmesi. Ortadoğu Tıp Dergisi, 11:294-302.

Köroğlu E, Güleç C (2007) Psikiyatri Temel Kitabı, 2. Baskı. Ankara, HYB Basın Yayın.

Levene JE, Lancee WJ, Seeman MV (1996) The perceived family burden scale: Measurement and validation. Schizophr Res, 22:151-157.

Maj M, Sartorius N (1999) Schizophrenia, 1st ed. New York, Wiley.

Mantovani LM, Ferretjans R, Marçal IM, Oliveira AM, Guimarães FC, Salgado JV (2016) Family burden in schizophrenia: The influence of age of onset and negative symptoms. Trends Psychiatry Psychother, 38:96-99.

Mehrotra K, Nautiyal S, Raguram A (2018) Mental health literacy in family caregivers: A comparative analysis. Asian J Psychiatry, 31:58-62.

Moreno-Küstner B, Martín C, Pastor L (2018) Prevalence of psychotic disorders and its association with methodological issues. A systematic review and meta-analyses. PLoS One. 13:e0195687..

Özdemir I, Şafak Y, Örsel S, Kahiloğulları AK, Karadağ H (2017) Bir toplum ruh sağlığı merkezinde şizofreni hastalarına uygulanan ruhsal-toplumsal uyumlandırma etkinliğinin araştırılması: Kontrollü çalışma. Anadolu Psikiyatri Derg, 18:419-427.

Pazvantoğlu 0, Sarısoy G, Böke 0̈, Aker AA, Özturan DD, Ünverdi E (2014) Şizofrenide bakım veren yükünün boyutları: Hastaların işlevselliğinin rolü. Dusunen Adam, 27:53-60.

Patikula M (2017) Kişilik inançlarının ruhsal hastalığa yönelik inançlar üzerine etkisi (Yüksek lisans tezi). İstanbul, Fatih Sultan Mehmet Vakıf Üniversitesi.

Rahmani F, Ranjbar F, Hosseinzadeh M, Razavi SS, Dickens GL, Vahidi M (2019) Coping strategies of family caregivers of patients with schizophrenia in Iran: A cross-sectional survey. Int J Nurs Sci, 6:148-153.

Rexhaj S, Jose AE, Golay P, Favrod J (2016) Perceptions of schizophrenia and coping styles in caregivers: comparison between India and Switzerland. J Psychiatr Ment Health Nurs, 23:585-594. 
Rhee TG, Rosenheck RA (2019) Does improvement in symptoms and quality of life in chronic schizophrenia reduce family caregiver burden? Psychiatry Res, 271:402-404.

Roick C, Heider D, Bebbington PE, Angermeyer MC, Azorin JM, Brugha TS et al. (2007) Burden on caregivers of people with schizophrenia: comparison between Germany and Britain. Br J Psychiatry, 190:333-338.

Sağduyu A, Aker T, Özmen E, Ögel K, Tamar D (2001) Halkın şizofreniye bakışı ve yaklaşımı üzerine bir epidemiyolojik araştırma. Turk Psikiyatri Derg. 12:99-110.

Sarıkoç G, Demiralp M, Özşahin A, Açıkel CH (2015) Ruhsal hastalıklarda yardım arama: hasta yakınlarının tutumlarına yönelik bir çalışma. Balıkesir Sağık Bilimleri Dergisi, 4:32-38.

Schene AH (1990) Objective and subjective dimensions of family burden. Towards an integrative framework for research. Soc Psychiatry Psychiatr Epidemiol, 25:289-297.

Segal DL, Coolidge FL, Mincic MS, O'Riley A (2005). Beliefs about mental illness and willingness to seek help: A cross-sectional study. Aging Ment Health, 9:363-367.

Siddiqui S, Khalid J (2019) Determining the caregivers' burden in caregivers of patients with mental illness. Pak J Med Sci, 35:1329-1333.

Shamsaei F, Cheraghi F, Bashirian S (2015) Burden on family caregivers caring for patients with schizophrenia. Iran J Psychiatry, 10: 239-245.

Soygür H (2016) Community mental health services: quo vadis?. Noro Psikiyatr Ars, 53:1-3.

T. C. Sağlık Bakanlığı (2011) Ulusal Ruh Sağlığı Eylem Planı (2011-2023). Ankara, Sağlık Bakanlığı.

Vigo D, Thornicroft G, Atun R (2016) Estimating the true global burden of mental illness. Lancet Psychiatry, 3:171-178.

Yalvaç HD, Kotan Z, Ünal S (2015) Şizofreni hastalarında çare arama davranışı ve ilişkili faktörler: Türkiye'nin doğusunda ve batısındaki iki popülasyon arasında karşılaştırmalı bir çalışma. Dusunen Adam, 28:154-161.

Yazıcı E, Karabulut Ü, Yıldız M, Baskan Tekeş S, İnan E, Çakır U et al. (2016) Şizofrenisi olan hastalara bakım verenlerin yükü ve ilişkili etmenler. Noro Psikiyatr Ars, 53:96-101.

Yıldırım A, Buzlu S, Hacıhasanoğlu Aşılar R, Camcıoğlu TH, Erdiman S, Ekinci M (2014) Şizofreni hastalarının ailelerine uygulanan aileden aileye destek programının hastalık hakkında bilgi, aile yükü ve öz yeterlilik üzerine etkisi. Turk Psikiyatri Derg, 25:1-7.

Yıldııım S, Ersoysal F, Güler C (2018) Acil servis çalışanlarının ruhsal hastalıklara yönelik inanç ve tutumlarının incelenmesi. Klinik Psikiyatri Dergisi, 21:380-388.

Yıldııım S, Yalçıner N, Güler C (2017) Caregiver burden in chronic mental illness: a systematic review. J Psychiatr Nurs, 8:165-171.

Yu Y, Liu ZW, Tang BW, Zhao M, Liu XG, Xiao SY (2017) Reported family burden of schizophrenia patients in rural China. PloS One, 12:e0179425.

Yu Y, Zhou W, Liu ZW, Hu M, Tan ZH, Xiao SY (2019) Gender differences in caregiving among a schizophrenia population. Psychol Res Behav Manag, 12:7-13.

World Health Organization (2013) Comprehensive Mental Health Action Plan 2013-2020. Geneva, World Health Organization.

World Health Organization (2019) Schizophrenia, key facts. https://www.who.int/news-room/fact-sheets/detail/schizophrenia (Accessed 2.2.2020). 
Yazarların Katkıları: Tüm yazarlar, her bir yazarın çalışmaya önemli bir bilimsel katkı sağladığını ve makalenin hazırlanmasında veya gözden geçirilmesinde yardımcı olduğunu kabul etmişlerdir.

Danışman Değerlendirmesi: Dış bağımsız

Etik Onay: Araştırma için Gazi Üniversitesi Etik Kurulundan onay alınmıştır. Tüm katılımcılar aydınlatılmıs onam vermişlerdir.

Çıkar Çatışması: Yazarlar çıkar çatışması bildirmemiştir.

Finansal Destek: Yazarlar bu çalışma için finansal destek almadıklarını beyan etmişlerdir

Authors Contributions: All authors attest that each author has made an important scientific contribution to the study and has assisted with the drafting or revising of the manuscript.

Peer-review: Externally peer-reviewed.

Ethical Approval: Ethical approval was obtained from Gazi University Ethics Committee for the study. All participants provided informed consent.

Conflict of Interest: No conflict of interest was declared by the authors.

Financial Disclosure: The authors declared that this study has received no financial support. 